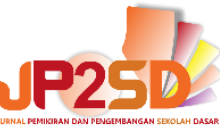

UNIVERSITAS MUHAMMADIYAH MALANG JP2SD (JURNAL PEMIKIRAN

DAN PENGEMBANGAN SEKOLAH DASAR)

http://ejournal.umm.ac.id/index.php/jp2sd

p-ISSN: 2338-1140 e-ISSN: 2527-3043

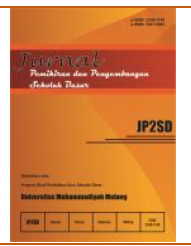

\title{
Pengembangan Karakter Siswa Melalui Kegiatan Home visit (Studi Kasus Tingkat Sekolah Dasar di Kabupaten Sumenep)
}

\author{
Mas'odi a ${ }^{\text {a1 }}$ Mufti Syaifuddin ${ }^{\text {a2 }}$, Amirullah ${ }^{\text {b3 }}$ \\ asTKIP PGSRI Sumenep, Indonesia \\ ${ }^{\mathrm{b}} \mathrm{SD}$ IT Al Hidayah Sumenep, Indonesia \\ 1'masodi@stkippgrisumenep.ac.id, ${ }^{2}$ muftis@stkippgrisumenep.ac.id ${ }^{3}$ amirullah.ak09@gmail.com
}

\begin{tabular}{ll}
\hline INFORMASI ARTIKEL \\
\hline Riwayat: & \\
Diterima & $30 \mathrm{Maret}$ \\
& 2020 \\
Revisi & $30 \mathrm{Mei}$ \\
& 2020 \\
Dipublikasikan & 20 September \\
& 2020
\end{tabular}

Kata kunci:

Home visit, pendidikan

karakter, sekolah dasar

\section{ABSTRAK}

Pembentukan karakter dan watak individu yang berdasarkan nilai dan norma yang berlaku di tengah-tengah lingkungan masyarakat di mana para siswa tinggal. Program kegiatan home visit sebagai langkah membuka peluang bagi pendidik untuk mengetahui karakter siswa. Tujuan penelitian ini untuk melihat bahwasanya perkembangan karakter kepada anak didik sekolah dasar menjadi satu kesatuan yang tidak dipisahkan dan bisa melalui berbagai cara, salah satunya melalui kegiatan home visit dalam rangka pengembangan karakter anak didik. Penggunaan metode penelitian pengembangan karakter melalui kegiatan home visit bersifat kualitatif dengan pendekatan studi kasus. Hasil penelitian antara lain menunjukkan tumbuh kembang karakter anak didik dalam segi kemandirian dan penerapan nilai-nilai keagamaan dan sosial. Pengembangan karakter anak melalui kegiatan home visit anak akan berlangsung dengan optimal ketika terjalin kerjasama yang baik antara orang tua dan guru.

\begin{tabular}{|c|c|}
\hline & ABSTRACT \\
\hline $\begin{array}{l}\text { Keywords: } \\
\text { Home visit, character } \\
\text { education, primary school } \\
\text { 口. }\end{array}$ & $\begin{array}{l}\text { The formation of individual character and character based } \\
\text { on the values and norms that apply in the community where } \\
\text { students live. The home visit activity program is a step to } \\
\text { open opportunities for educators to find out the character of } \\
\text { students. The purpose of this study was to see that the } \\
\text { character development of elementary school students } \\
\text { became an inseparable unit and could go through various } \\
\text { ways, one of which was through a home visit in order to } \\
\text { develop the character of students. The use of character } \\
\text { development research methods through home visit activities } \\
\text { is qualitative with a case study approach. The results of the } \\
\text { study, among others, showed the character development of } \\
\text { students in terms of independence and the application of } \\
\text { religious and social values. The development of children's }\end{array}$ \\
\hline
\end{tabular}


character through children's home visit activities will take place optimally when there is good cooperation between parents and teachers.

How to cite: Mas'odi, Mufti Syaifuddin, Amirullah. (2020). Pengembangan Karakter Siswa Melalui Kegiatan Home visit (Studi Kasus Tingkat Sekolah Dasar di Kabupaten Sumenep). Jurnal Pemikiran dan Pengembangan Sekolah Dasar, Vol 8 No 2, 107-117. doi: https://doi.org/10.22219/jp2sd.v8i2.11734

\section{PENDAHULUAN}

Kegiatan belajar mengajar di sekolah tidak sepenuhnya optimal mengingat kondisi belajar mengajar yang kurang kondusif. Kurang kondusifnya proses belajar di kelas bisa diakibatkan oleh beberapa faktor, seperti seorang guru yang harus mengajarkan banyak pelajaran, kurang meratanya perhatian guru kepada anak didik, atau juga target kurikulum yang harus terselesaikan tepat pada waktunya. Kondisi yang telah disebutkan secara tidak langsung bisa memberi dampak pada pelaksanaan belajar mengajar yang bersifat teknis, terlebih pada siswa yang masih perlu mendapat perhatian dalam proses belajar mengajar. Mengingat pendidikan memiliki sistem pendidikan yang berkelanjutan. Perlu upaya optimal untuk menjadi pondasi bagi anak didik sebelum melanjutkan ke jenjang pendidikan selanjutnya.

Guru merupakan figur sentra dalam pendidikan, peran guru sangat dibutuhkan dalam proses belajar mengajar. Proses belajar mengajar bukan semata-mata hanya mengajarkan apa yang tertulis di dalam buku dan menyampaikan dalam bentuk kalimat di depan anak didik. Peran penting guru tidak hanya sebatas mengajar tentang materi di kelas, namun juga tidak kalah penting adalah tentang pembentukan karakater dan watak individu anak didiknya. Pembentukan karakter dan watak individu yang berdasarkan nilai dan norma yang berlaku di tengah-tengah lingkungan masyarakat di mana para siswa tinggal (Kirom, 2017).

Kerjasama antara guru dan wali murid sangatlah di perlukan untuk menunjang keberhasilan proses belajar mengajar. Sekolah melalui guru kelas (wali kelas) sangat perlu menjalin komunikasi dengan orang tua (wali murid). Komunikasi yang terjalin di kedua belah pihak antara sekolah dengan orang tua diharapkan dapat menciptakan suasana yang harmonis. Alasan penting perlunya komunikasi antara sekolah dengan orang tua adalah perlunya saling pengertian agar segala program sekolah yang ada dapat terealisasikan dengan baik dalam bentuk kegiatan yang nyata. Program dan kegiatan yang dimaksud adalah melalui kegiatan kunjungan rumah (home visit).

Melalui upaya kunjungan rumah (home visit), merupakan satu langkah penting dalam melakukan pendekatan pendidikan dalam rangka menumbuhkan karakter dan watak anak didik. Pola kerjasama diharapkan juga tumbuh antara wali murid dengan guru dalam mengenali dan memahami anak didik sebagai peserta didik yang dilibatkan. Kegiatan home visit secara mendasar memiliki tujuan untuk mengetahui kondisi siswa di rumah dengan maksud memperoleh berbagai keterangan dan informasi dengan mendasarkan pada pemahaman lingkungan dan permalasahan siwa yang memiliki nilai guna penyelesaian lahan siswa terkait. Tidak hanya itu saja, melalui home visit diharapkan juga guru dapat mengetahui kebiasaan siswa di rumah, seperti kebiasaan belajar, kemandirian di rumah, pola hubungan siswa dengan orang tua dan lingkungan sekitar tempat tinggal siswa dan perilaku sosial lainnya selama di luar sekolah.

Konsep Home visit memiliki arti sebagai kunjungan rumah. Lebih luas lagi konsep home visit memiliki maksud sebagai kegiatan pendukung kegiatan belajar dalam konteks

Mas'odi, dkk. Pengembangan Karakter Siswa Melalui Kegiatan Home visit (Studi Kasus Tingkat Sekolah Dasar di Kabupaten Sumenep) 
bimbingan konseling. Kegiatan tersebut meliputi aktifitas memperoleh data, informasi, atau keterangan lain yang memiliki keterkaitan. Data dan informasi yang ada nantinya digunakan sebagai bahan penyelesaian dari permasalahan yang ada, maka dari itu kegiatan home visit memerlukan kerjasama yang penuh dari orang tua dan keluarga lain.Kegiatan home visit pada arti lain memiliki makna sebagai bentuk upaya untuk mendeteksi kondisi keluarga sebagai kaitannya dengan permasalah yang dimiliki seorang individu yang menjadi tanggung jawab seorang pendidik (Sukardi, 2008).

Pelaksanan home visit pada dasarnya memiliki tujuan sebagai pengenalan lingkungan hidup anak didik. Tenaga pendidik atau guru secara tidak langsung membutuhkan informasi tentang kondisi anak didik yang tidak nampak pada perilaku kegiatan di sekolah. Tujuan lain dari home visit yang dilakukan seorang pendidik setidaknya bisa mendapatkan data tentang siswa, lebih khususnya yang memiliki keterkaitan dengan kondisi lingkungan tempat tinggalnya. Tujuan lain yang tidak kalah penting dari pelaksanaan home visit adalah sebuah upaya dari lembaga pendidik untuk membangun komitmen orang tua untuk turut tanggung jawab dan bekerja sama dalam menyelesaikan permasalahan anak terkait (Rahman, 2003).

Program kegiatan home visit sebagai langkah membuka peluang bagi pendidik untuk mengetahui karakter siswa. Langkah tersebut bisa terwujud apabila kerjasama orang tua dan pendidik dapat terjalin dengan baik. Suasana yang menyenangkan merupakan strategi yang haru diciptakan. Mewujudkan komunikasi yang efektif merupakan langkah penting agar terhindar dari kesalapahaman sebagai proses mengembangkan potensi anak baik di sekolah maupun di rumah. Membangun persepesi yang sama antara pendidikan di sekolah dengan pendidikan di rumah diharapkan dapat menciptakan suasana harmonis bagi siswa sehingga kedepannya mereka memiliki kemampuan dan kemandirian dalam mengembangkan potensi yang ada. Senada dengan penelitian yang dilakukan oleh (Rafika et al., 2017) diketahui bahwa seorang guru harus memberikan motivasi dan perencanaan pembelajaran dengan baik. Tentu perencanaan disini juga tak lepas dari bagaimana merencanakan komnikasi yang baik dengan para orang tua/wali murid.

Konsep pendidikan pada dasarnya telah tertuang di dalam Undang-Undang No. 20 Pasal 3 Tahun 2003 tentang Sistem Pendidikan Nasional (UNDANG-UNDANG REPUBLIK INDONESIA NOMOR 20 TAHUN 2003 TENTANG SISTEM PENDIDIKAN NASIONAL, 2003). Isi yang dimaksud dalam Undang-Undang tersebut kurang lebihnya menyatakan, bahwa pendidikan nasional memliki fungsi untuk mengembangkan dan membentuk watak serta peradaban bangsa yang bermartabat dalam rangka mencerdaskan kehidupan bangsa, bertujuan untuk berkembangnya potensi peserta didik agar menjadi manusia yang beriman dan bertaqwa kepada Tuhan Yang Maha Esa, berakhlak mulia, sehat, berilmu, cakap, kreatif, mandiri, dan menjadi warga negara yang demokratis serta bertanggung jawab.

Amanat pendidikan karakter sebagaimana tertuang pada Undang-Undang tersebut mensiratkan bahwa pendidikan karakter sangatlah perlu untuk ditanamkan kepada anak didik agar dapat menjadi individu yang memiliki rasa keimanan dan ketakwaan kepada Tuhan Yang Maha Esa. Kesadaran keimanan dan ketakwaan kepada Tuhan Yang Maha Esa diharapkan dapat menjadi kontrol sosial dari perbuatan pelanggaran nilai dan norma yang berlaku di masyarakat.

Proses pembelajaran pendidikan karakter memerlukan perlunya sebuah tindakan nyata dalam proses internalisasi. Pendidikan karakter cenderung tidak akan pernah berhasil dengan nyata jika proses pembelajarannya hanya sebatas proses pemahaman

Mas'odi, dkk. Pengembangan Karakter Siswa Melalui Kegiatan Home visit (Studi Kasus Tingkat Sekolah Dasar di Kabupaten Sumenep) 
tentang karakter atau hanya sebatas penjelasan teori saja. Perlu adanya komitmen nyata dan sikap yang konsisten sebagai kunci utama dalam penerapan pendidikan karakter kepada anak didik. Langkah tersebut sebagaia upaya pendidikan karakter yang memiliki sifat pembelajaran pada proses step by step. Satu hal yang perlu menjadi acuan bahwa pendidikan bukan hanya diberikan secara teks di sekolah, tapi juga perlu diterapkan dalam kehidupan sehari-hari, sehingga kedepannya akan menjadi kebiasaan.

Pendidikan karakter yang ditanamkan kepada anak didik memiliki fungsi sebagai upaya untuk mengatasi permasalahan kurang optimalnya pendidikan informal dalam lingkungan keluarga. Kesibukan dan padatnya aktivitas orang tua dalam bekerja, kurangnya pemahaman orang tua dalam mendidik anak di lingkungan keluarga, pengaruh pergaulan di lingkungan sekitar dan pengaruh media elektronik bisa memberikan dampak langsung ataupun tidak langsung yang bersifat negatif terhadap perkembangan anak didik. Pendidikan karakter hadir sebagai salah satu alternatif penanggulangan persoalan pendidikan yang ada.

Pembentukan karakter kepada anak pada dasarnya tidak hanya pada peran orang tua saja, namun bisa saja bisa dipengaruhi dari lingkungan sekitar. Sekolah merupakan lingkungan kedua setelah lingkungan keluarga. Tidak salah apabila pembentukan karakter seorang anak juga tidak terlepas dari pendidikan di sekolah melalui guru-guru yang ada Seperti yang disampaikan oleh (Yuliyatun, 2013) "Sekolah merupakan lembaga pendidikan yang keberadaannya sangat menentukan para guru untuk benar-benar dapat menanamkan nilai-nilai pendidikan (values of education) kepada peserta didik". Guru sebagai tenaga pendidik dengan segala perilaku sosial yang dimainkan secara tidak langsung mampu mempengaruhi karakter peserta didik. Karakter yang dimaksud memiliki tiga bentuk bagian dan saling berkaitan, antara lain ; pengetahuan moral, perasaan moral, dan perilaku moral (Lickona, 2012).

Penelitian ini memiliki tujuan untuk melihat bahwasanya perkembangan karakter kepada anak didik sekolah dasar menjadi satu kesatuan yang tidak dipisahkan dan bisa melalui berbagai cara, salah satunya melalui kegiatan home visit dalam rangka pengembangan karakter anak didik. Sejauh pengetahuan peneliti dan berdasarkan hasil observasi yang ada bisa disimpulkan hingga tulisan penelitian ini di buat belum ada penelitian yang menunjukkan penelitian tentang perkembangan karakter anak didik melalui kegiatan home visit. Beberapa penelitian sebelumnya yang berhasil dihimpun antara lain menunjukkan, pertama, kegiatan home visit memiliki pengaruh dalam meningkatkan motivasi belajar siswa di SD IT Harapan Bunda Purwokerto (Dwita et al., 2018).

Kedua, penelitian tentang pentingnya pelaksanaan home visit oleh guru bimbingan dan konseling yang dilakukan Puji G. H. dan Hafis Hidayat. Hasil penelitian menunjukkan pentingnya kegiatan home visit oleh bimbingan konseling dalam meningkatkan hasil belajar siswa. Pelayanan home visit perlu dilakukan oleh guru bimbingan konseling (Handayani \& Hidayat, 2017).

Ketiga, penelitian tentang implementasi home visit dalam upaya meningkatkan pembelajaran PAI di SDIT Al Azhar Kediri. Hasil penelitian menunjukkan home visit sebagai sarana komunikasi antara guru dan orang tua. Kegiatan home visit sebagai upaya meningkatkan pembelajaran yang memiliki penekanan pada aspek kognitif, afekti, dan psikomotor (Dwita et al., 2018).

Keempat, penelitian mengenai pentingnya pendidikan karakter. Penelitian sebagai hasil pemikiran tentang perlunya langkah-langkah dan strategi pendidikan karakter di

Mas'odi, dkk. Pengembangan Karakter Siswa Melalui Kegiatan Home visit (Studi Kasus Tingkat Sekolah Dasar di Kabupaten Sumenep) 
lingkungan rumah oleh orang tua. Tujuan penelitian ini memberikan gambaran kepada orang tua pentingnya pendidikan karakter di dunia pendidikan (Omeri, 2015).

Kelima, penelitian tentang kajian program home visit di tingkat pendidikan anak usia dini pada keluarga kurang sejahtera. Hasil penelitian menunjukkan perlunya program home visit pada keluarga kurang sejahtera sebagai upaya peningkatan kualitas pendidikan pada anak usia dini. Melalui kegiatan home visit pada anak keluarga kurang sejahtera diharapkan dapat memenuhi kebutuhan tumbuh kembang anak usia dini (Komalasari, 2015).

Pendidikan karakter dalam penerapannya tidak hanya saja menjadi tanggung jawab guru, namun juga menjadi tanggung jawab semua stakeholder pendidikan yang memiliki keterkaitan, terlebih para pemangku kebijakan menjadi garda depan dalam pembangunan dan pengembangan pendidikan karakter pada masyarakat.

\section{METODE}

Penelitian ini bersifat kualitatif dengan penggambaran peristiwa yang terekam dalam proses penelitian. Sementara itu pendekatan yang digunakan dalam penelitian ini dengan pendekatan Studi Kasus. Penelitian ini menggunakan sampel dari dua sekolah. Pemilihan tersebut merupakan sekolah yang hanya memiliki kegiatan home visit di kabupaten Sumenep. Setiap sekolah nanti diambil masing-masing sampel sebanyak delapan sampel kegiatan home visit. Sekolah-sekolah sampel berdasarkan rekomendasi dari data bagian pendidikan dasar yang terdapat di dinas pendidikan kabupaten/kota terkait penelitian.

Metode pengumpulan data menggunakan wawancara dengan penggunaan panduan pedoman wawancara. Sebelum panduan wawancara digunakan dalam pengambilan data, data pedoman wawancara di uji cobakan dahulu untuk mendapatkan kedalaman wawancara. Pengumpulan data tidak hanya sebatas wawancara, namun juga menggunakan pengamatan untuk mencocokkan jawaban subyek penelitian dengan perilaku yang ada. Hasil wawancara yang telah terkumpul selanjutnya di buat ringkasan, terutama mengenai substansi yang menjadi fokus penelitian.

Pengolahan data dengan cara mengelompokkan atau mengkategorikan dengan membuat kode-kode untuk setiap kategori yang ada. Data dikelompokan menjadi beberapa kelompok, antara lain : konsep home visit, aktivitas belajar mengajar, dan hasil belajar mengajar. Proses pengkodean mengacu pada tata cara coding yang telah ada di analisis penelitian grounded theory.

Penggunaan analisis data melalui pengorganisasian data penelitian yang terkumpul dengan catatan lapangan, gambar (foto), dokumen dan sebagainya. Tahap berikutnya melalui reduksi data dengan cara pemilihan, pemusatan perhatian, pengabstrakan, dan transformasi data dari catatan lapangan yang berupa reduksi data secara terus menerus selama penelitian berlangsung. Memasuki tahap selanjutnya dengan penyajian data dari sekumpulan informasi yang telah tersusun dengan berbagai kemungkinan untuk penarikan kesimpulan dan pengambilan tindakan atau dengan melakukan verifikasi data (Huberman, 2017).

\section{HASIL DAN PEMBAHASAN}

\section{Home visit Sebagai Upaya Membangun Kemandirian}

Proses pendidikan karakter terhadap seorang individu atau lazim ditujukan kepada anak didik memerlukan adanya pondasi kuat dalam keberhasilan menumbuh kembangkan kemampuan karakter anak didik. Pondasi kuat yang di maksud sebagai keberhasilan

Mas'odi, dkk. Pengembangan Karakter Siswa Melalui Kegiatan Home visit (Studi Kasus Tingkat Sekolah Dasar di Kabupaten Sumenep) 
tumbuh kembang kemampuan karakter anak terdapat pada kemampuan anak didik terhadap kemandirian dan kedisiplinan. Kemandirian dan kedisiplinan merupakan cerminan perangkat kemampuan dan pengetahuan dengan adanya kesadaran dan kemauan disertai tindakan untuk melaksanakan nilai dan norma yang berlaku di tengahtengah masyarakat. Mendasarkan pada pernyataan tersebut, kemandirian dan kedisiplinan terasa harus ada dalam pendidikan karakter. Proses keberhasilan kemandirian dan kedisiplinan pada sisi konsep pendidikan karakter menjadi akhir sebagai nilai akhir (kristalisasi) pendidikan karakter yang telah terinternalisasi pada kebiasaan anak didik. Proses kemandirian dan kedisiplinan sebagai bagian dari pendidikan karakter anak didik dalam perkembangan individu (pribadi) anak didik memberikan pengaruh tersendiri pada berbagai kemampuan lain yang dimiliki anak didik terkait. Maksud kemampuan lain pada anak didik sebagai pengaruh kemandirian dan kedisiplinan bisa meliputi, antara lain : kemampuan pengendalian sosial, kemampuan interaksi, kepemimpinan, dan juga pada tingkat akademik dan non akademik yang dimiliki anak didik.

Kemampuan pengendalian sosial yang terlahir sebagai pengaruh dari kemandirian dan kedisiplinan memberikan kemampuan dan pengetahuan kepada anak didik untuk menerapkan perilaku yang sadar terhadap adanya larangan dan perintah atau anjuran untuk patuh sesuai dengan nilai dan norma yang berlaku. Kepatuhan terhadap nilai dan norma yang berlaku di tengah-tengah masyarakat secara tidak langsung memiliki punishment dan reward bagi individu (anak didik) yang mematuhi atau juga melanggar nilai dan norma yang telah berlaku. Tersedianya punishment dan reward memberikan pengaruh psikologi kepada anak didik. Perbuatan yang memperoleh reward akan senantiasa cenderung diulangi, mengingat anak didik memiliki sebagai individu memiliki kebutuhan untuk diakui sebagai hasil dari prestasinya. Sebaliknya punishment yang diperoleh seorang anak didik memberikan kecenderungan rasa jera untuk tidak mengulanginya. Tindakan kepatuhan yang dijalankan oleh anak didik sebagai bentuk perilaku yang memiliki tujuan untuk menciptakan ketertiban sosial di lingkungan sekitar anak didik, baik di sekolah atau juga di tempat tinggal. Kemampuan perilaku sebagai wujud pengendalian sosial merupakan keberlanjutan dari pola sosialisasi yang diperoleh anak didik baik dari lingkungan keluarga atau juga dari lingkungan lembaga pendidikan. Melalui kemampuan pengendalian sosial, anak didik juga belajar untuk bersikap konformitas yang disertai sikap disiplin dan mandiri.

Kemampuan lain sebagai pengaruh dari sikap kemandirian dan kedisiplinan ialah mengasah kemampuan interaksi anak didik untuk lebih memiliki rasa kepedulian, baik rasa empati atau juga rasa simpati. Tidak kalah penting dari itu, bentuk lain dari interaksi sosial sebagai pengaruh dari kemandirian dan kedisiplinan bisa memberikan kemampuan anak didik untuk memiliki kemampuan identifikasi terhadap persoalan yang dihadapi atau terhadap lingkungan sekitar dari anak didik. Kemampuan identifikasi yang dimiliki seorang anak didik bisa tumbuh seiring dengan kemampuan kemandirian dan kedisiplinan yang terus berproses. Mengingat konsep identifikasi pada seorang individu (anak didik) akan mulai timbul ketika seorang anak didik mulai memiliki kesadaran bahwa di dalam kehidupan bermasyarakat terdapat berbagai nilai dan norma yang harus dipelajari, dipenuhi, dan ditaati. Proses kemampuan identifikasi pada anak didik juga mengajarkan untuk mengenali antara yang baik dan yang tidak baik atau juga antara yang boleh dan yang tidak boleh. Proses awal anak didik mengasah kemampuan interaksi pada bentuk identifikasi memerlukan panduan dari orang dewasa. Kemampuan identifikasi dari yang dimiliki individu pada masa anak-anak bisa terus berkembang di masa dewasa dengan lebih mampu melakukan identifikasi dari setiap perilaku, sikap, dan perspektif yang ada

Mas'odi, dkk. Pengembangan Karakter Siswa Melalui Kegiatan Home visit (Studi Kasus Tingkat Sekolah Dasar di Kabupaten Sumenep) 
untuk dikumpulkan hingga pada titik tertentu dipelajarinya serta dikembangkan sebagai pedoman atau panduan bagi perilaku sehari-hari.

Melalui kemandirian dan kedisiplinan yang tertananm sejak dini telah memberikan kemampuan leadership (kepemimpinan) pada anak didik. Kemampuan leadership yang muncul secara mendasar merupakan upaya anak didik untuk membangun keyakinan dan upaya konsistensi pembiasaan diri dengan nilai dan norma yang berlaku di lingkungan sekitar anak didiknya. Kesungguhan anak didik yang memiliki kemampuan kepemimpinan menjadikan pribadi yang tidak rentan terhadap godaan, tidak pantang menyerah terhadap masalah yang dihadapi, serta tak lupa pula bisa menumbuhkan rasa kepercayaan dari individu lain kepada anak didik. Terpenting dalam mempertahankan kemampuan kepemimpinan pada anak didik adalah dengan pembiasaan yang terarah dan terencana, tentunya hal ini perlu kerjasama dari lembaga pendidikan dengan orang tua selaku lingkungan anak didik yang primer dalam pola pengasuhan dan pengajaran yang terpenting menjaga kemandirian dan kedisiplinan. Kemampuan kepemimpinan yang dimiliki anak didik dari proses kemandirian dan kedisiplinan bisa terlihat dari adanya inisiatif yang dimiliki oleh anak didik itu sendiri. Inisiatif yang dimiliki oleh anak bisa terlihat pada kemampuannya menyelesaikan masalah, mengelola diri sendiri dengan lingkungan sekitarnya, atau juga juga anak didik bisa menyadarkan dan mengarahkan diri sendiri untuk lebih baiak dari hari keharinya.

Upaya membangun, menjaga, dan menumbuhkembangkan kemampuan kemandirian dan kedisiplinan sebagai salah satu proses untuk menunjang keberhasilan akademik ataupun akademik yang tengah dipelajari oleh anak didik. Paramater keberhasilan anak didik dibidang akademik tidaklah sama dengan parameter keberhasilan anak didik di bidang non akademik apabila anak didik memiliki kemampuan di dua hal tersebut, namun setidaknya kemandirian dan kedisiplinan yang dimiliki anak didik melalui pembiasan yang ada bisa menjadi kunci utama kemampuan anak didik untuk belajar membagi waktu dan juga belajar untuk memberikan prioritas utama yang menjadi pilihan bagi anak didik. Prioritas untuk memilih bidang yang ditekuni oleh anak didik tentunya memerlukan bimbingan dan tuntunan orang tua atau juga guru dalam menentukan arah pendidikan yang sesuai dengan kemampuan dan kebutuhan anak didik.

\section{Home visit Sebagai Kontrol Norma Agama}

Pembangunan dan tumbuh kembang karakter anak didik tidak bisa terpisahkan dari adanya norma agama. Anak didik sebagai manifestasi individu yang berkarakter memiliki kewajiban menjaga dirinya dari kebathilan dan senantiasa menghindarkan dirinya segala perbuatan yang tercela. Tidak kalah penting adalah terdapatnya upaya dalam dirinya untuk selalu mengembangkan ilmu pengetahuan, kedisiplinan diri dan peningkatan keimanan serta ketaqkwaan kepada Tuhan Yang Maha Esa. Agama menjadi panduan dan tuntunan terpenting dalam setiap tumbuh kembang anak didik "...apa yang Kami kehendaki sampai waktu yang sudah ditentukan, kemudian Kami keluarkan kamu sebagai bayi, kemudian (dengan berangsur-angsur) kamu sampailah kepada kedewasaan, dan di antara kamu ada yang diwafatkan dan (adapula) di antara kamu yang dipanjangkan umurnya sampai pikun...." (Qur'an, 2020).

Islam sebagai salah satu agama yang berkembang memiliki nilai dan norma yang selalu senantiasa harus di jaga dan dipatuhi oleh umatnya. Melalui perjalanan perkembangan agama Islam telah memberikan proses pembelajaran yang tidak kalah penting tentang karakter atau juga dalam istilah lain di sebut akhlak. Nabi Muhammad Saw, sebagai pembawa ajaran agama Islam telah menjadi suri tauladan umatnya dan telah

Mas'odi, dkk. Pengembangan Karakter Siswa Melalui Kegiatan Home visit (Studi Kasus Tingkat Sekolah Dasar di Kabupaten Sumenep) 
membuat karakter Islam sepanjang perjalanan beliau berjuang menegakkan risalah Allah. Karakter keagamaan Islam dibangun oleh Rasullah berlandaskan akidah (iman). Rasa tidak mudah menyerah dan tidak mengenal ditunjukkan oleh Rasullah dalam membangun akidah keislamaan yang bersifat fundamental pada saat itu. Apa yang dilakukan Rasulallah merupakan cerminan adanya pendidikan karakter yang diberikan oleh Nabi Muhammad Saw kepada umatnya. Akidah menjadi kunci penting dalam melaksanakan keseluruhan ketentuan yang telah ada. Ketentuan agama Islam merupakan ajaran yang harus dipatuhi. Kepatuhan yang utuh baik pada segi kualitas dan kuantitas merupakan cerminan muslim yang berkarakter. Nabi telah memberikan contoh karakter mulia, begitu juga para sahabat nabi, maka ada kewajiban bagi setiap muslim untuk terus mengikuti karakter mulia seperti yang dicontohkan Rasulallah.

Mendekatkan anak didik dengan nilai-nilai keagamaan Islam merupakan upaya membangun dan mengembangkan potensi karakter keagamaan anak didik sesuai dengan suri tauladan Nabi Muhammad Saw. Kehadiran agama pada segi pengajaran dan pembalajaran bukan semata-mata sebagai formalitas belaka. Anak didik perlu pembiasaan yang tidak berhenti pada pengajaran nilai-nilai keagamaan Islam pada pengajaran dan pembelajaran di lembaga pendidikan sekolah. Keberlanjutan penerapan nilai-nilai keagamaan Islam di tempat tinggal jauh lebih penting untuk menumbuhkan anak didik yang memiliki karakter keagamaan. Pentingnya karakter dari nilai-nilai agama memberikan pendidikan yang utuh bagi individu, terlebih pendidikan karakter. Kehadiran ilmu pengetahuan bagi pendidikan karakter tanpa dibarengi nilai-nilai agama akan menjadi buta dan kehilangan makna penting pendidikan karakter itu sendiri. Nilai-nilai agama menjadi solusi penting sebagai tolak ukur dalam mengukur sebuah kebaikan dan keburukan, atau baik dan salah yang tidak terbatas hanya saja hubungan sesama manusia, namun juga pada hubungan antara manusia dengan Tuhan.

Lingkungan yang menjaga nilai-nilai keagamaan sangatlah penting dalam proses pendidikan karakter anak didik. Pembinaan karakter pada dasarnya juga pada pembinaan akhlak. Anak didik yang berada pada lingkungan yang menjunjung dan menjaga nilainilai keagamaan mengalami pembiasaan akan pentingnya pembentukan akhlak sesuai dengan nilai norma keagamaan yang dianutnya. Pembiasaan akhlak pada kehidupan bermasayarakat lebih memberikan penghargaan pada sikap sopan santun, rasa saling hormat menghormati, dan juga kejujuran. Tidak dapat dipungkiri memang pada saat ini terdapat perubahan pemahaman bahwasanya nilai keagamaan hanya sebatas teks tertulis saja, bukan pada konteks yang ada. Kegiatan home visit yang dilakukan oleh lembaga pendidikan pada dasarnya sebagai upaya untuk menjadi ruang komunikasi dan diskusi dalam pelaksanaan pemahaman nilai-nilai keagamaan yang kontekstual. Ruang semacam ini menjadi penting untuk menjembatani tumbuh kembang anak didik yang berkarakter sesuai denga nilai-nilai keagamaan.

Pendidikan karakter berlandaskan nilai-nilai keagamaan pada aspek lebih luas juga harus dilakukan kepada makhluk Allah yang lain, seperti tumbuhan, binatang, dan lingkungan alam semesta yang tidak kasat mata. Upaya pendidikan karakter semacam ini secara tidak langsung memberikan isyarat kepada manusia akan tugasnya khalifah di muka bumi atas semua makhluk Allah yang ada. Manusia yang memahami akan penciptaan Allah merupakan cerminan manusia yang berkarakter sebagaimana yang telah dicontohkan oleh Rasulallah. Sejatinya setiap apa yang diciptakan oleh Allah telah memiliki tugas dan fungsinya masing-masing.

Mas'odi, dkk. Pengembangan Karakter Siswa Melalui Kegiatan Home visit (Studi Kasus Tingkat Sekolah Dasar di Kabupaten Sumenep) 


\section{Home visit dan Peran Orang Tua Dalam Pengembangan Karakter}

Peran aktif orang tua dalam proses pendidikan karakter anak merupakan hal terpenting untuk membangun dan mengembangkan karakter anak agar lebih optimal seiring tumbuh kembang anak. Orang tua dalam konteks pranata keluarga memiliki fungsi primer dalam mensosialisasikan setiap nilai dan norma dalam menumbuhkembangkan karakter anak untuk sesuai dengan lingkungan yang ada. Melalui sosialisasi, pembiasaan atau pembudayaan karakter yang sesuai dengan nilai dan norma yang berlaku mulai dilakukan demi terwujudnya karakter yang sesuai dengan harapan dan tujuan akhir dari suatu proses pendidikan yang telah dilakukan orang tua. Keputusan orang tua dalam memilih lembaga pendidikan yang dipercaya dan diyakini merupakan sebagai salah satu langkah orang tua untuk membangun karakter anak di lingkungan yang di nilai bisa mewujudkan harapan dan keinginan orang tua terkait pendidikan karakter anak "Dimanapun pendidikan dengan berbagai tingkatan atau strata harus dilibatkan untuk membangun karakter melalui investasi nilai dan memperkuat nilai karakter dengan cara mengajar dan mendidiknya kepada siswa kita di keluarga (orang tua) dan sekolah: sekolah umum atau madrasah. Tampaknya peran orang tua dan sekolah itu sendiri membutuhkan kerjasama sinergis untuk mengembangkan karakter siswa" (Syahroni, 2017) bahkan (Hatimah, 2016) juga menyatakan bahwa “...adanya kolaborasi antara keluarga dan sekolah berpengaruh meningkatkan kemajuan dan kesusksesan anak-anaknya”.

Pengawasan dan arahan orang tua kepada anak dirumah sangatlah penting dalam menunjang tumbuh kembang pendidikan karakter anak didik. Guru sebagai pemangku pembelajaran di sekolah melalui home visit berusaha membuka ruang diskusi dan komunikasi mengenai kerjasama dalam memenuhi kebutuhan pendidikan karakter bagi setiap individu anak didik yang beraneka ragam kepribadian. Peran orang tua dalam pola pengasuhan dan pengawasan sangatlah penting, maka dari itu orang tua lebih diharapkan memilih sikap yang selektif dalam memenuhi setiap kebutuhan anak didik. Orang tua diharapkan tidak terjebak dengan setiap keinginan anak didik dalam proses pembelajaran pendidikan karakter. Keteladanan perilaku orang tua menjadi dasar paling utama dalam keberlangsungan pendidikan karakter yang ada di dalam keluarga. Melalui keteladanan perilaku orang tua sejatinya telah memberikan contoh nyata bagaimana pendidikan karakter telah diajarkan oleh orang tua. Peran pengajaran orang tua dalam memberikan keteladanan perilaku sehari-hari telah mampu menjadikan sebagai kebiasaan yang tertanam di dalam benak anak didik untuk berperilaku yang sama dengan orang tuanya. Pembiasaan perilaku baik yang telah terbawa dari rumah diharapkan bisa terbawa hingga di bangku sekolah, maka dengan sendirinya akan muncul proses saling berkelanjutan antara pendidikan karakter yang diperoleh di rumah dan sekolah (Syahraeni, 2015).

Terwujudnya pendidikan karakter kepada anak didik memerlukan adanya proses pembudayaan karakter. Pendidikan karakter dapat diintegrasikan dalam pembelajaran secara masif melalui beragam media perantara (Kuncahyono, 2018). Pembudayaan karakter yang dilakukan memerlukan sinergi kerjasama antara orang tua, lembaga pendidikan, atau juga lingkungan sekitar yang memiliki hubungan dengan perkembangan anak didik. Peran orang tua sangatlah penting dalam proses pembudayaan karakter tersebut, karena orang tua harus menjalankan fungsinya sebagai pengawas dan pendidikan. Pembudayaan karakter bisa terwujud dengan optimal apabila ada kultur atau budaya yang bisa menjadi parameter dalam menuntun dan menjadi panduan setiap perilaku serta tindakan anak didik. Kultur atau budaya merupakan kebiasaan yang berlandaskan tradisi dengan memiliki nilai-nilai tertentu yang terus tumbuh dan berkembang seiring dinamika kehidupan masyarakat dengan berbagai aspek yang

Mas'odi, dkk. Pengembangan Karakter Siswa Melalui Kegiatan Home visit (Studi Kasus Tingkat Sekolah Dasar di Kabupaten Sumenep) 
meliputinya. Setiap pendidikan karakter yang disampaikan kepada anak didik dapat menyesuaikan atau bahkan membentuk dan mengembangkan kultur yang ada sesuai dengan tujuan pendidikan karakter yang tengah terinternalisasi kepada anak didik.

Tidak dapat dipungkiri bahwa proses pembelajaran pendidikan karakter di lingkungan keluarga tidak selamanya berjalan sesuai dengan rencana. Munculnya beberapa hambatan merupakan tantangan yang harus dihadapi oleh orang tua atau juga dengan anggota keluarga lainnya. Kesibukan orang tua atau juga kondisi emosional yang sedang dihadapi orang tua merupakan sedikit contoh hambatan proses pendidikan karakter kepada anak. Rasa afeksi (perasaan) yang berlebihan merupakan bentuk emosional yang bersifat negati dalam pola pengasuhan anak didik, hingga terkadang mendorong orang tua bersikap manja kepada anak. Tentunya sikap tersebut bisa menjadi penghalang pendidikan karakter kepada anak didik. Bersikap sebaliknya terlalu keras kepada anak juga bukan pilihan yang bijak. Ada baik orang tua memberikan ruang komunikasi kepada anak didik akan kebutuhan pola asuh yang menyenangkan bagi anak didik dan orang tua itu sendiri.

Kegiatan home visit yang dilakukan oleh lembaga pendidikan merupakan salah satu cara mengenali karakter anak didik dan berusaha membantu mengatasi permasalahan anak didik dalam berproses menjadi individu yang optimal dengan segala kemampuan yang ada. Keberlangsungan kegiatan home visit sangat berarti ketika orang tua wali murid berkenan untuk masuk dalam ruang komunikasi dan diskusi yang telah disediakan oleh lembaga pendidikan melalui kegiatan home visit itu sendiri. Segala hasil home visit yang telah dilakukan diharapkan dapat menjadi bahan pembenahan dan penyelesaian permasalahan anak didik, meski hal tersebut membutuhkan langkah yang konsisten dan berkelanjutan antara orang tua dengan lembaga Pendidikan "Pembentukan sifat dan karakter pendidikan tidak akan pernah berhasil selama diantara ketiga lingkungan pendidikan tidak ada keharmonisan dan kesinambungan. Melihat kenyataan ini, membentuk karakter siswa yang berkualitas diperlukan pengaruh yang kuat dari keluarga, sekolah, dan mayarakat" (Subianto, 2013).

\section{SIMPULAN}

Mendasarkan pada permasalahan, perolehan data serta hasil pembahasan setidaknya dapat disimpulkan mengenai pengembangan karakter anak didik melalui kegiatan home visit di kabupaten Sumenep. Kegiatan home visit sebagai salah satu cara dalam menumbuhkembangkan karakter anak didik untuk lebih bersikap mandiri dalam kegiatan sehari-hari. Kemandirian yang terjadi tidak hanya di lingkungan pendidikan saja, namun juga lebih penting di lingkungan tempat tinggal anak didik. Pengembangan karakter anak didik melalui kegiatan home visit tidak hanya dalam kemandirian dalam arti empirik saja. Melalui kegiatan home visit anak didik memiliki tumbuh kembang karakter dalam segi nilai-nilai keagamaan. Nilai-nilai keagamaan tumbuh melalui kesadaran anak didik sebagai bagian dari kontrol sosial dalam pembentukan karakter. Pengembangan karakter anak didik melalui kegiatan home visit bisa berjalan optimal ketika terjalin kerjasama yang baik antara orang tua dan guru pembimbing. Program kegiatan home visit berjalan dengan maksimal orang tua dan guru saling bersinergi untuk pengembangan karakter anak didik.

Mas'odi, dkk. Pengembangan Karakter Siswa Melalui Kegiatan Home visit (Studi Kasus Tingkat Sekolah Dasar di Kabupaten Sumenep) 


\section{REFERENSI}

Dwita, K. D., Anggraeni, A. I., \& Haryadi. (2018). Pengaruh Home Visit dan Motivasi Belajar Terhadap Hasil Belajar Siswa di SDIT Harapan Bunda Purwokerto. Jurnal Ekonomi, Bisnis, Dan Akuntansi, 20(01), 1-15.

Handayani, P. G., \& Hidayat, H. (2017). Pentingnya pelaksanaan home visit oleh guru bimbingan dan konseling. PROCEEDINGS | JAMBORE KONSELOR 3(2017), $3,168-177$.

Hatimah, I. (2016). Keterlibatan Keluarga Dalam Kegiatan Di Sekolah Dalam Perspektif Kemitraan. Pedagogia, 14(2), 290-297. https://doi.org/10.17509/pedagogia.v14i2.3878

Huberman, M. dan. (2017). Analisis Data Kualitatif. Jakarta. UI Press.

Kirom, A. (2017). Peran Guru Dan Peserta Didik Dalam Proses Pembelajaran Berbasis Multikultural. Al Murabbi:Jurnal Pendidikan Agama Islam, 3(1), 69-80.

Komalasari, E. (2015). Layanan home visit pendidikan anak usia dini bagi anak kurang sejahtera. Ta'dib, 18(137).

Kuncahyono, K. (2018). INTEGRASI PENDIDIKAN KARAKTER PADA PEMBELAJARAN TEMATIK MELALUI MEDIA BERBASIS KOMPUTER DI SEKOLAH DASAR. Seminar Nasional Lembaga Kebudayaan (SENASGABUD), 1(1).

Lickona, T. (2012). Character matters (persoalan karakter) bagaimana membantu anak mengembangkan penilaian yang baik, integritas, dan kebajikan penting lainnya. Bumi Aksara.

Omeri, N. (2015). Pentingnya pendidikan karakter dalam dunia pendidikan. Manajer Pendidikan, 9(3), 464-468.

Qur'an, A. (2020). Qur'an Kemenag. LPMQ. https://quran.kemenag.go.id/

Rafika, Israwati, \& Bachtiar. (2017). Upaya Guru Dalam Menumbuhkan Kemandirian Belajar Siswa di SD Negeri 22 Banda Aceh. Jurnal Ilmiah Pendidikan Guru Sekolah Dasar, 2, 115-123.

Rahman, H. (2003). Bimbingan dan Konseling Pola 17. Ucy Press.

Subianto, J. (2013). Peran Keluarga, Sekolah, Dan Masyarakat Dalam Pembentukan Karakter Berkualitas. Edukasia : Jurnal Penelitian Pendidikan Islam, 8(2), 331354. https://doi.org/10.21043/edukasia.v8i2.757

Sukardi, D. K. (2008). Proses Bimbingan dan Konseling. Rineka Cipta.

Syahraeni, A. (2015). TANGGUNG JAWAB KELUARGA DALAM PENDIDIKAN ANAK Dosen. Jurnal Bimbingan Penyuluhan Islam, 2(1), 27-45.

Syahroni, S. (2017). Peranan Orang Tua dan Sekolah dalam Pengembangan Karakter Anak Didik. Intelektualita, 6(1), 13. https://doi.org/10.19109/intelektualita.v6i1.1298

UNDANG-UNDANG REPUBLIK INDONESIA NOMOR 20 TAHUN 2003 TENTANG SISTEM PENDIDIKAN NASIONAL, 147 (2003).

Yuliyatun. (2013). Peranan Bimbingan dan Konseling Islam di Sekolah. KONSELING RELIGI: Jurnal Bimbingan Konseling Islam, 4(2), 343-370. 